\title{
PENINGKATAN USAHA MINUMAN SARIDELE DI KOTA SURABAYA
}

\author{
Rena Febrita Sarie ${ }^{1}$, Dwi Lesno Panglipursari ${ }^{2}$, Yurilla Endah Muliatie ${ }^{3}$, Nur Jannah ${ }^{4}$, \\ Pramandyah Fitah Kusuma ${ }^{5}$ \\ 1, 2, 3, 4, 5 Universitas Wijaya Putra \\ renafebritasarie@uwp.ac.id, dwilesno@uwp.ac.id, yurillaendah@uwp.ac.id, nurjannah@uwp.ac.id, , \\ pramandyahfitah@uwp.ac.id
}

\begin{abstract}
Abstrak
Program Pengabdian Masyarakat dalam semester ini adalah mengembangkan Usaha Kecil Mandiri (UKM) produksi minuman Saridele di Kecamatan Sawahan Surabaya. Permasalahan yang dihadapi saat ini adalah pemasaran yang terbatas pada segmen pasar tertentu dalam lingkup yang kecil. Untuk mengatasi masalah pemasaran yang terbatas maka kami menawarkan pemasaran produk saridele pada segmen pasar yang lebih luas agar hasil produksi saridele dapat terjual lebih banyak. Penjualan yang lebih luas wilayahnya akan dapat meningkatkan pendapatan usaha mitra UKM.

Dalam rangka untuk mempertahankan kontinuitas operasional usaha dimasa yang akan datang juga diperlukan tata kelola manajemen usaha yang lebih baik dan dimungkinkan juga memberdayakan usaha kerjasama dengan mitra lain non wirausahawan. Implementasi program pengabdian ini antara lain meliputi: 1) Memberikan pelatihan produksi minuman Saridele. 2) Melakukan pendampingan dalam memilih pasar potensial, promosi dan lokasi penjualan. 3) Memberikan pendampingan pembuatan merk/logo kemasan. 4) Memberikan pelatihan dan pendampingan dalam menentukan varian cita rasa minuman saridele. 5) Memberikan pelatihan dan pendampingan dalam menentukan biaya produksi. 6) Memberikan pelatihan dan pendampingan dalam penyusunan laporan keuangan.

Dengan adanya kegiatan ini diharapkan penjualan bisa meningkat sehingga meningkat pula pendapatan yang diperoleh. Tetapi dengan adanya penerapan PPKM, hasil penjualan tidak sesuai dengan target yang diharapkan.
\end{abstract}

Kata Kunci: peningkatan, usaha saridele, UKM

\section{PENDAHULUAN}

Kedelai merupakan salah satu jenis kacangkacangan yang mengandung protein nabati yang tinggi sumber lemak, vitamin, dan mineral (Endrasari \&Nugrasari: 2012). Kedelai mengandung protein $35 \%$ bahkan pada varietas unggul kadar proteinnya dapat mencapai 40-43\% dibandingkan dengan beras, jagung, tepung, singkong, kacang hijau, daging, ikan segar, dan telur ayam. Kedelai mempunyai kandungan protein yang lebih tinggi, hampir menyamai kadar protein susu skim kering (Setiavani:2012). Produk olahan kedelai dapat dikelompokkan menjadi dua yaitu produk makanan non fermentasi dan makanan terfermentasi (Widowati:2007). Salah satu produk olahan susu kedelai nonfermentasi modern adalah susu kedelai.

Susu kedelai belakangan ini banyak diperbincangkan terutama di kalangan vegetarian. 
Selain rasanya yang enak, susu kedelai juga memiliki manfaat yang baik untuk tubuh kita.

Susu kedelai adalah minuman yang kaya nutrisi yang dapat menjadi sumber protein, karbohidrat, gula, serat, dan lemak yang baik. Susu kedelai juga kaya akan mineral dan vitamin yang bermanfaat bagi tubuh.

Beberapa manfaat susu kedelai antara lain adalah:

Satu, membantu proses pertumbuhan dimana susu kedelai ini mendukung proses tumbuh kembang pada anak-anak yang sedang dalam masa pertumbuhan. Hal ini karena kandungan susu kedelai yang kaya akan protein. Protein memegang peranan penting untuk memberikan nutrisi pada tubuh. Selain itu, kedelai adalah salah satu sumber protein nabati terbaik. Selain karena memiliki kandungan yang tinggi, ia juga mudah dicerna oleh tubuh.

Dua, membantu menurunkan kolesterol dimana susu kedelai mengandung protein yang terbuat dari asam amino yang memiliki keuntungan mencegah berbagai penyakit. Asam amino dan isoflavon yang terkandung dalam susu kedelai memiliki fungsi untuk menurunkan kadar kolesterol dalam darah. Dengan mengomsumsi makanan yang rendah kolesterol, tubuh akan terhindar dari berbagai penyakit kardiovaskuler seperti penyakit jantung, stroke dan sebagainya.

Tiga, membantu menurunkan tekanan darah. Beberapa penelitian membandingkan susu kedelai dengan susu sapi dalam menurunkan tekanan darah. Didapatkan bahwa susu kedelai mampu menurunkan tekanan darah lebih baik dibandingkan dengan susu sapi pada pasien dengan hipertensi ringan sampai sedang. Oleh karena itu penderita hipertensi sangat dianjurkan untuk mengatur pola makan dengan mengonsumsi makanan yang baik untuk menjaga tekanan darah seperti susu kedelai.

Empat, membantu mengontrol gula darah. Menurut penelitian yang diterbitkan dalam Archives Internal Medicine, menyebutkan bahwa konsumsi makanan yang diolah dari biji-bijian dapat membantu mengontrol gula darah pada penderita diabetes. Diantara pasien dengan diabetes tipe 2, konsumsi susu kedelai memiliki efek yang baik untuk tekanan darah dan gula darah. Hal ini karena susu kedelai mengandung indeks glikemik yang rendah.

Lima, membantu menurunkan berat badan. Manfaat susu kedelai selanjutnya sebagai menu diet yang baik untuk menurunkan berat badan dan mencegah obesitas. Hal ini karena kandungan protein yang tinggi pada kedelai.

Enam, mengurangi gejala post-menopause. Susu kedelai dapat mengurangi masalah kesehatan pada wanita setelah menopause. Beberapa penelitian menemukan bahwa isoflavon pada kedelai dapat menjaga kadar estrogen pada wanita postmenopause. Sistem imun dapat tertekan setelah menopause karena efek penuaan dan berkurangnya estrogen. Isoflavon adalah komponen yang mengandung bahan estrogenik dan antioksidan, sehingga bisa membantu menguatkan daya tahan tubuh pada wanita pada periode ini.

Tujuh, memberi nutrisi bagi ibu hamil. Kedelai yang terdapat pada susu kedelai mengandung folat atau vitamin B9. Kedua zat ini berperan penting sebagai nutrisi untuk ibu hamil. Menurut penelitian yang diterbitkan dalam Nutrition Journal, ibu yang mengonsumsi kedelai selama proses kehamilan memiliki plasenta yang lebih sehat dan berat janin yang baik.

Delapan, mencegah osteoporosis. Manfaat susu kedelai lainnya adalah mengurangi kemungkinan terjadinya osteoporosis. Osteoporosis merupakan resiko yang dialami wanita pada usia menopause atau pada usia lanjut. Kandungan kalsium yang terdapat pada susu kedelai berperan untuk mencegah pengeroposan pada tulang yang seringkali terjadi akibat proses penuaan.

Sembilan, menjaga kesehatan tulang dan gigi. Secara umum tubuh membutuhkan kalsium untuk menjaga kesehatan tulang dan gigi. Kalsium dibutuhkan oleh segala usia, terutama anak-anak.

Sepuluh, membantu proses pembekuan darah. Selain untuk membantu proses penyerapan Kalsium, vitamin $\mathrm{K}$ juga membantu proses pembekuan darah. Pembekuan darah dibutuhkan 
oleh tubuh dalam menyembukan luka dan cedera. Vitamin K yang terdapat pada susu kedelai berperan menghasilkan protrombin yaitu protein khsus yang berfungsi untuk pembekuan darah dan metabolisme tulang.

Sebelas, menurunkan risiko kanker usus. Hal ini karena kandungan butyrate yang terdapat pada kedelai. Butyrate adalah jenis bakteri baik yang berfungsi sebagai anti inflamasi.

Dua belas, mengurangi kanker prostat. Hal ini karena kandungan isoflavon pada kedelai yang bertindak sebagai anti karsinogenik atau zat yang berfungsi untuk mencegah kanker.

Tiga belas, mencegah kanker payudara. Kandungan phytoestrogens pada produk olahan kedelai dapat mencegah perkembangan sel kanker payudara pada tubuh manusia.

Empat belas, membantu menjaga kesehatan hati. Susu kedelai mengandung isoflavon yang dapat memberi efek antioksidan pada tubuh. Antioksidan ini berperan untuk membantu menurunkan stres oksidatif dan mencegah kerusakan pada hati. Isoflavon dapat membantu kinerja hati dalam menawarkan zat-zat beracun yang masuk ke dalam tubuh. Manusia dapat terkena zat beracun yang berasal dari makanan yang mengandung bahan kimia berbahaya dan polusi.

Lima belas, melancarkan pencernaan. Hal ini karena kandungan serat pangan yang tinggi pada susu kedelai. Dengan mengonsumsi susu kedelai secara rutin dapat memenuhi kebutuhan serat yang diperlukan oleh tubuh. Serat dapat membantu agar terhindar dari berbagai masalah pencernaan seperti susah buang air besar, wasir dan sembelit.

Produk Minuman Susu kedelai sangat disukai oleh semua kalangan di Indonesia. Melalui beberapa kajian riset minuman ini banyak mengandung vitamin dan nutrisi untuk kesehatan tubuh. Susu kedelai merupakan susu dengan harga murah, memiliki nilai gizi tinggi serta cocok untuk semua golongan usia tua dan muda (Rhina \& Erlyna:2016).

Pemanfaatan minuman saridele ini telah dikenal sejak dahulu. Minuman saridele saat ini telah diproses dengan menggunakan berbagai macam bahan termasuk dicampur dengan buah-buahan sehingga menghasilkan produk yang menyehatkan bagi tubuh. Produk berupa susu kedelai dipilih sebagai usaha untuk berwirausaha karena mempunyai prospek yang baik saat ini. Setiap tahun permintaan konsumen akan kebutuhan minuman Saridele terus meningkat, terlebih saat ini konsumen sedang menggiatkan untuk mengkonsumsi makanan dan minuman sehat untuk memperkuat imun tubuh agar tahan terhadap virus Corona. Hal ini membuat para pengusaha UKM Minuman Saridele dituntut terus untuk meningkatkan produktivitas dan kualitas produknya.

Pertimbangan Tim Pengusul terhadap pemilihan mitra kerja ada satu UKM didasarkan atas hasil survei di lokasi mitra UKM di Simo Gunung Kramat Selatan No. 44, Surabaya Sehingga mitra UKM dipandang layak menjadi mitra kerjasama untuk melaksanakan Program Pemberdayaan Masyarakat (PPM) tahun anggaran 2020/2021.

Identitas mitra UKM, nama dan alamat tempat usahanya adalah sebagai berikut: Mitra UKM "Saridele" Ibu Supini warga Simo Gunung Kramat Selatan no 44 Kecamatan Sawahan Kota Surabaya.

Kondisi mitra saat ini belum dikatakan sejahtera diukur dari hasil usahanya, yang hanya cukup untuk memenuhi kebutuhan hidup dan keperluan sehari-hari dalam sebulan, sehingga belum memiliki sisa dana sebagai tabungan.

Hal tersebut disebabkan oleh kemampuan memproduksi minuman Saridele hanya dengan menggunakan peralatan manual dan hasil produksi hanya cukup memenuhi kebutuhan/permintaan konsumen dengan jumlah terbatas pada pasar konsumen tertentu. Jumlah produksi hanya rata-rata hanya 75 botol perhari. Dengan keterbatasan output produksi, tenaga kerja yang digunakan oleh mitra hanya berjumlah 2 orang, sebagai tenaga produksi merangkap tugas pengiriman barang. saridele:

Berikut adalah tabel penjualan minuman Ekonomi, Sosial dan Budaya 1069 


\section{Tabel 1. Penjualan Minuman Saridele Mitra PPM}

\begin{tabular}{|c|l|c|c|c|l|c|}
\hline No. & $\begin{array}{c}\text { Nama } \\
\text { UKM }\end{array}$ & $\begin{array}{c}\text { Beban } \\
\text { Pokok } \\
\text { Produksi } \\
(\mathrm{Rp})\end{array}$ & $\begin{array}{c}\text { Hasil Penjualan } \\
\text { @Rp.4000/ } \\
\text { Botol } \\
(\mathrm{Rp})\end{array}$ & $\begin{array}{c}\text { Keuntungan } \\
\text { Per Bulan } \\
(\mathrm{Rp})\end{array}$ & $\begin{array}{c}\text { Peralatan } \\
\text { Produksi }\end{array}$ & $\begin{array}{c}\text { Hasil } \\
\text { Produksi }\end{array}$ \\
\hline 1 & Ibu Supini & 4.875 .000 & 7.800 .000 & 2.925 .000 & Manual & 1950 Botol \\
\hline & Jumlah & $\mathbf{4 . 8 7 5 . 0 0 0}$ & $\mathbf{7 . 8 0 0 . 0 0 0}$ & $\mathbf{2 . 9 2 5 . 0 0 0}$ & Manual & 1950 Botol \\
\hline
\end{tabular}

Permasalahan yang dihadapi oleh mitra antara lain adalah:

Satu, permasalahan di bidang manajemen dimana diperlukan penataan manajemen usaha di bidang produksi, pemasaran dan keuangan. Solusi yang ditawarkan adalah perlunya diversifikasi produk dengan menambahkan varian rasa yang diharapkan dengan adanya varian rasa konsumen bisa bebas membuat pilihan produk dengan rasa manakah yang akan dibeli. Kemudian juga perlu dilakukan pem-branding-an premium ataupun pemberian branding berdasarkan permintaan konsumen untuk resale. Sehingga para reseller dapat dengan mudah memasarkan produknya. Selain itu hal yang penting untuk dilakukan adalah mencari segmen pasar yang lebih luas. Tidak hanya menitipkan barang dagangan di pasar tapi juga di tempat-tempat lain seperti misalnya, di minimarket, di kantor-kantor ataupun tempat-tempat strategis lainnya. Dan hal terakhir yang harus dilakukan dari permasalah di bidang manajemen ini adalah melakukan promosi untuk meningkatkan penjualan. Promosi yang dilakukan tidak hanya dari mulut ke mulut atau words of mouth tetapi juga melalui media sosial. Baik itu dari whatsapp, facebook, instagram maupun dari platform media sosial lainnya.

Kedua, permasalahan permodalan dimana perlu adanya penambahan modal kerja. Solusi yang ditawarkan adalah memberikan pendampingan untuk mendapatkan bantuan modal kerja dari lembaga keuangan. Salah satu solusi yang sudah dilakukan adalah dengan membantu pendaftaran untuk mendapatkan bantuan pemerintah untuk usaha mikro (BPUM) yang dilakukan ke RT/RW setempat yaitu dengan mengumpulkan berkasberkas yang menunjukkan bahwa mitra adalah benar-benar pelaku usaha mikro dan selama ini belum mendapatkan sentuhan permodalan dari pihak manapun.

Ketiga, permasalah di bidang produk dimana mitra saat ini kekurangan tenaga kerja di bagian produksi dan pengiriman barang ke konsumen. Selama ini produksi dilakukan sendiri oleh mitra sehingga hasil produksi tidak maksimal. Solusi yang ditawarkan adalah dengan memberikan pendampingan dalam perekrutan tenaga kerja sehingga mitra dapat meningkatkan hasil produksi dan dapat lebih mudah mengirimkan hasil produksinya kepada konsumen atau reseller.

\section{METODE}

Metode pengabdian masyarakat yang dimaksud dengan metode disini ialah pola atau sistim tindakan yang akan dilakukan, ataupun urutan atau tahapan-tahapan yang perlu dalam menjalankan kegiatan pengabdian-pengabdian kepada masyarakat. (Pradana, 2021).

Adapun tahapan-tahapan yang perlu diikuti adalah sebagai berikut:

Memberikan penyuluhan, pelatihan praktis serta pendampingan.

Mitra diberikan penyuluhan dan pelatihan praktis antara lain:

Pertama, dalam hal penataan/pengelolaan bidang usaha yang meliputi tugas, wewenang dan tanggung jawab pekerjaan masing-masing personil yang berada di dalam tata kelola organisasi usaha mitra UKM. Memberikan pelatihan administrasi dan sistem pencatatan dokumen transaksi keuangan (pembukuan) serta pelaporan keuangannya. Dari yang sebelumnya hanya dengan pencatatan secara manual dan sederhana sehingga tidak bisa dilihat berapa keuntungan yang di dapat. Bahkan mitra menerapkan manajemen saku dimana modal dan keuntungan dipergunakan tidak pada porsinya, dalam artian modal dipergunakan juga untuk kehidupan sehari-hari sehingga adakalanya mitra kehabisan modal karena tidak bisa dikontrol 
penggunaannya.

Dengan adanya pengabdian pada masyarakat ini mitra mulai mengerti untuk memisahkan uang modal dan keuntungan dan tidak menggunakan dengan tidak bertanggung jawab sehingga bisnis bisa berkembang sesuai yang diharapkan.

Penambahan tenaga kerja pemasaran/penjualan atau pengiriman barang. Dengan adanya penambahan tenaga kerja ini pengiriman produk kepada pembeli dan reseller semakin cepat.

Kedua, memotivasi semangat usaha mitra UKM guna peningkatan kesejahteraan hidupnya. Dengan adanya pandemi sekarang ini, kehidupan semakin susah dan ada pula yang semakin terpuruk. Pengabdi berusaha memompakan semangat kepada mitra untuk berjuang dan untuk tetap menjual produknya walaupun terkena imbas PPKM darurat. Keteguhan mitra saat ini benar-benar diuji dan pandemi ini bisa dijadikan ajang penggemblengan diri sehingga mitra bisa lebih kuat menahan terpaan badai di kemudian hari.

Ketiga, melakukan evaluasi atas pelaksanaan kegiatan usaha mitra UKM setelah kegiatan PKM selesai.

Kegiatan ini diharapkan dapat berhasil sesuai dengan yang diharapkan. Tetapi dengan adanya PPKM darurat hasil yang diharapkan mungkin tidak semaksimal yang diharapkan.

Bahan-bahan kebutuhan produksi harganya juga melonjak sehingga membuat mitra harus benarbenar pandai mengaturnya supaya harga jual produknya tidak ikut naik pula.

Dengan adanya varian rasa baru selain rasa original diharapkan bisa mendongkrak penjualan minuman Saridele meskipun terimbas oleh PPKM.

\section{HASIL DAN PEMBAHASAN}

\section{Target Luaran}

Target luaran yang ingin dicapai dari pengabdian masyarakat ini antara lain adalah:
Satu, untuk penataan manajemen usaha di bidang produksi, pemasaran dan keuangan, target luaran yang diharapkan adalah peningkatan omzet penjualan sebagai hasil dari adanya diversifikasi produk dengan menambahkan varian rasa, pembranding-an, segmen pasar yang tepat dan promosi di media sosial.

Kedua, untuk penambahan modal kerja, target luaran yang diharapkan adalah peningkatan kapasitas produksi sebagai hasil dari pendampingan untuk mendapatkan bantuan modal kerja dari lembaga keuangan maupun bantuan pemerintah untuk usaha mikro.

Ketiga, untuk penambahan tenaga kerja di bagian produksi dan pengiriman barang ke konsumen maupun reseller, target luaran yang diharapkan adalah peningkatan produksi dan kecepatan pengiriman barang ke konsumen dan reseller sebagai hasil dari pendampingan dalam perekrutan tenaga kerja.

\section{Pembahasan}

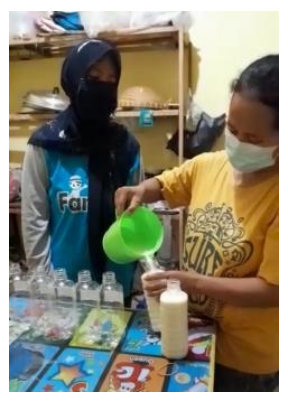

Gambar 1. Pengemasan Saridele dengan menggunakan botol

Pengabdi memberikan pendampingan kepada mitra dalam memproduksi saridele dalam hal pengemasan produk dimana pengemasannya menggunakan botol plastik dari yang sebelumnya menggunakan gelas plastik. Pengemasan dengan menggunakan botol plastik terlihat lebih higienis dan bisa membuat produksi lebih tahan lama. Meskipun memang harga jual menjadi lebih mahal tetapi pelanggan tidak melihat harga yang harus mereka bayar karena produk yang ditawarkan adalah produk yang menggunakan bahan-bahan yang berkualitas dan bukan bahan-bahan sintesis 
atau kimia serta pengemasan yang juga higienis.

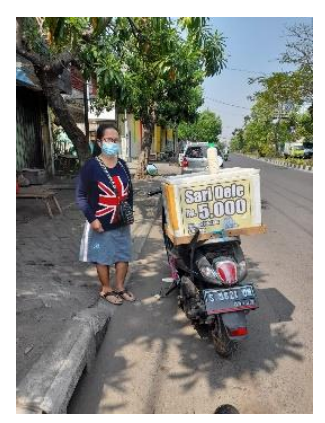

Gambar 2. Penjualan saridele di pinggir jalan

Sebelum mendapatkan pendampingan, mitra Saridele menjual produknya di pinggir jalan dan bahkan mitra harus masuk dari kampung ke kampung menggunakan motor. Menawarkan dagangannya dari pintu ke pintu. Mitra harus merasakan teriknya matahari dan bahkan harus berbasah-basahan di musim hujan.

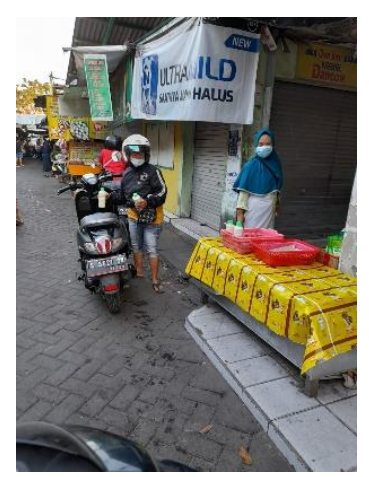

Gambar 3. Penjualan Saridele di pasar

Mitra juga menjual Saridele dengan cara dititipkan di lapak-lapak di pasar. Sebelum masa PPKM darurat banyak produk Saridele yang terjual dengan sistem ini tetapi semenjak masa PPKM darurat banyak produk Saridele yang harus kembali. Produk yang dikembalikan akan dimasukkan freezer untuk kemudian dijual lagi keesokan harinya.

Sebelum pandemi, mitra hanya berjualan di depan sekolah saja dan itu omzetnya luar biasa. Ada juga pesanan dari beberapa orang untuk dijual di tempat lain.
Tetapi setelah pandemi dan sekolah ditutup mitra hanya mengandalkan penjualan dengan cara titip jual di pasar.

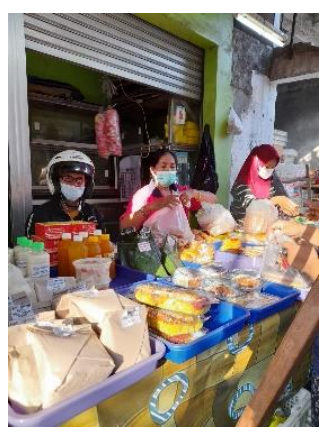

Gambar 4. Penjualan Saridele di lapak

Penjualan Saridele pada lapak-lapak di pasar. Ada beberapa lapak tempat mitra menitipkan produknya. Tetapi selama PPKM darurat beberapa lapak tutup sehingga omzet penjualan menjadi menurun. Dan juga selama masa PPKM darurat banyak produk Saridele yang harus dikembalikan karena tidak laku dijual.

Setelah mendapatkan pendampingan dari pengabdi, dengan adanya diversifikasi produk Saridele mengalami peningkatan dalam penjualan varian rasa coklat dan stroberi. Tetapi secara keseluruhan penjualan Saridele mengalami penurunan.

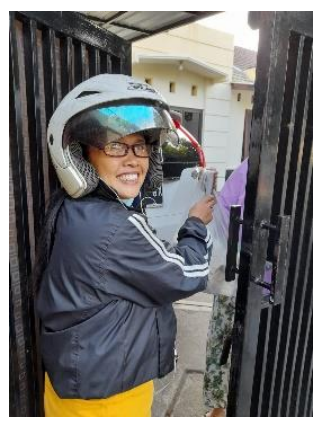

Gambar 5. Mitra mengantar pesanan Saridele kepada pelanggan yang memesan secara online

Sebelumnya mitra hanya menjual produknya secara offline, dari pintu ke pintu dan ada beberapa yang dititipkan sebagai produk konsinyasi di pasar. Setelah mendapatkan 
pendampingan dari pengabdi untuk mempromosikan produknya melalui media sosial, mitra mulai mendapatkan orderan secara online.

Pengabdi juga mendaftarkan produk saridele ini pada platform gofood dan grabfood.

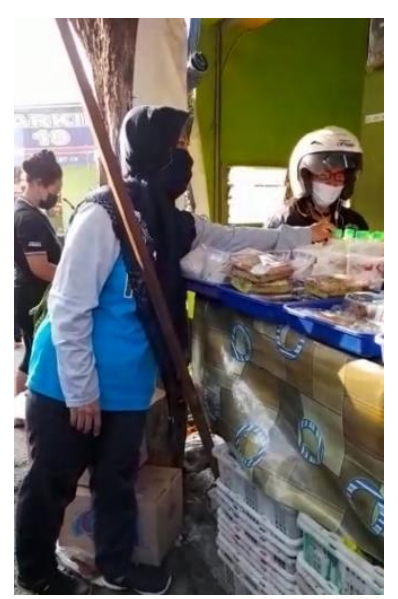

Gambar 6. Menata produk Saridele di lapak

Display yang menarik akan menarik minat pembeli untuk membeli produk dagangan kita. Dalam hal ini pengabdi juga memberikan cara-cara pen-display-an barang dagangan kepada mitra. Pengabdi mendampingi mitra dalam men-display produknya sehingga pembeli akan langsung mengenali produk Saridele buatannya dan tertarik untuk membeli.

Hasil penjualan minuman Saridele selama masa PPKM darurat bisa dilihat pada tabel di bawah ini:

Tabel 2. Penjualan Minuman Saridele Selama Masa PPKM Darurat

\begin{tabular}{|c|l|c|c|c|c|c|}
\hline No. & $\begin{array}{c}\text { Nama } \\
\text { UKM }\end{array}$ & $\begin{array}{c}\text { Beban } \\
\text { Pokok } \\
\text { Produksi } \\
(\mathrm{Rp})\end{array}$ & $\begin{array}{c}\text { Hasil Penjualan } \\
\text { @Rp.4000/ } \\
\text { Botol } \\
(\mathrm{Rp})\end{array}$ & $\begin{array}{c}\text { Keuntungan } \\
\text { Per Bulan } \\
(\mathrm{Rp})\end{array}$ & $\begin{array}{c}\text { Peralatan } \\
\text { Produksi }\end{array}$ & $\begin{array}{c}\text { Hasil } \\
\text { Produksi }\end{array}$ \\
\hline 1 & Ibu Supini & 4.875 .000 & 7.200 .000 & 2.325 .000 & Manual & 1800 Botol \\
\hline & Jumlah & $\mathbf{4 . 8 7 5 . 0 0 0}$ & $\mathbf{7 . 2 0 0 . 0 0 0}$ & $\mathbf{2 . 3 2 5 . 0 0 0}$ & Manual & 1800 Botol \\
\hline
\end{tabular}

Dari tabel diatas bisa dilihat bahwa terjadi penurunan omzet dikarenakan masa PPKM darurat. Hasil produksi sebelumnya adalah sebanyak 1950 botol minuman Saridele dengan keuntungan sebesar Rp. 2.925.00,- atau sebesar dua juta sembilan ratus dua puluh lima ribu rupiah. Tetapi selama masa
PPKM darurat hasil produksi hanya sebanyak 1800 botol minuman Saridele saja dengan total keuntungan sebesar Rp. 2.325.000,- atau sebesar dua juta tiga ratus dua puluh lima ribu rupiah. Terjadi penurunan sebesar Rp. 600.000,- atau sebesar enam ratus ribu rupiah per bulan.

Hal ini tentu saja dirasakan sangat berat bagi mitra yang penghidupannya hanya berjualan Saridele saja. Dan mitra berharap sesudah pandemi ini berlalu omzet penjualan bisa sesuai yang ditargetkan. Karena dengan adanya pendampingan ini sebenarnya sudah bisa dilihat jika berhasil hanya saja kondisi saat ini memang tidak memungkinkan. Hal ini dibuktikan dengan meningkatnya penjualan varian rasa baru daripada yang original. Penjualan online juga ada meskipun tidak terlalu banyak.

\section{SIMPULAN}

Kesimpulan dari hasil kegiatan pengabdian kepada masyarakat ini antara lain adalah:

Satu, kegiatan di bidang manajemen yang meliputi kegiatan dibidang produk, pemasaran dan keuangan adalah baik. Hal ini dibuktikan dengan meningkatnya penjualan minuman saridele varian rasa baru seperti misalnya rasa coklat dan stroberi, pengemasan produk dengan menggunakan kemasan botol yang memberikan kesan lebih higienis dimana mitra saridele ini hanya menggunakan bahan-bahan yang berkualitas untuk produksinya. Mitra tidak menggunakan bahan-bahan sintesis atau kimia dalam memproduksi saridele sehingga bisa dipastikan rasa dan aroma dari produk ini berbeda dari produk-produk yang lain yang menggunakan bahan sintesis atau kimia. Pemasaran pada platform media sosial yang tidak terbatas pada orang-orang di lingkungan sekitar mitra tetapi juga di luar area mitra. Dengan promosi di media sosial menjadikan produk saridele ini menjadi lebih terkenal daripada sebelumnya.

Tetapi hal yang patut disayangkan adalah dikarenakan penerapan PPKM darurat di Jawa dan Bali omzet yang ditargetkan tidak sesuai harapan. Terdapat penurunan omzet tetapi mitra berharap dengan berakhirnya PPKM darurat keadaan akan kembali normal dan omzet yang diharapkan bisa 
tercapai.

Mitra yang dulunya setiap hari bisa menjual 75 botol saridele selama masa PPKM darurat hanya bisa menjual 40-50 botol saridele saja. Penurunan ini sangat signifikan dan dirasa sangat berat bagi mitra.

Kedua, kegiatan pendampingan untuk penambahan modal kerja telah terlaksana dengan baik dimana mitra sudah berhasil mendaftarkan usahanya untuk mendapatkan bantuan dari pemerintah.

Ketiga, kegiatan pendampingan perekrutan tenaga kerja sudah terlaksana dengan baik. Hal ini dibuktikan telah direkrutnya 2 orang tenaga kerja. Satu orang sebagai tenaga produksi dan satu orang lagi sebagai kurir dalam pengiriman produk kepada konsumen atau reseller.

Saran yang diberikan oleh pengabdi terhadap mitra adalah untuk mempertahankan kualitas produk dengan tetap menggunakan bahanbahan yang berkualitas dan tidak menggunakan bahan-bahan kimia atau sintesis lainnya. Sehingga rasa dan aroma yang diberikan bisa memberikan semacam rasa ketagihan kepada pelanggan untuk kembali membeli produknya.

Meskipun saat ini kita berada di masa PPKM darurat Jawa dan Bali tetapi pengabdi mengharapkan mitra tidak patah semangat dalam melakukan usahanya. Karena pengabdi yakin bahwa badai ini akan segera berlalu dan keadaan akan berubah menjadi lebih dari sekarang.

Proses penggilingan saridele sebenarnya menghasilkan ampas kedelai yang masih bisa dimanfaatkan untuk menghasilkan produk baru yang bermanfaat. Ampas kedelai yang dihasilkan mitra biasanya langsung dibuang, tetapi pengabdi memberikan saran untuk bisa diolah kembali menjadi temen menjes atau nugget ayam yang menyehatkan. Dengan demikian akan meningkatkan nilai dari ampas kedelai menjadi produk lain yang dapat membantu ekonomi keluarga mitra khususnya di saat PPKM seperti ini.

\section{UCAPAN TERIMAKASIH}

Ucapan terimakasih disampaikan kepada Universitas Wijaya Putra Surabaya yang telah telah menerima pengabdian kepada masyarakat ini melalui hibah Abmas internal UWP.

\section{REFERENSI}

Endrasari R, Nugrasari D. (2012). Pengaruh Berbagai Cara Pengolahan Sari Kedelai Terhadap Penerimaan Organoleptik Dalam Prosiding Seminar Nasional Optimalisasi Pekarangan Semarang (ID): Undip Press.

Hastari, Sri, dkk. (2021). Peningkatan Nilai Produk Melalui Pendampingan Packaging dan Pemasaran Yang Menarik Pada Industri Rumahan Susu di Desa Sekarputih Kabupaten Pasuruan. Jurnal ABDINUS: Jurnal Pengabdian Nusantara, 5 (1), 2021, 160-167.

Pradana, Eka Yudhistira, dkk. (2021). Meningkatkan Ekonomi Mandiri Usaha Susu Kedelai di Masa Pandemi Covid-19. Among Jurnal Pengabdian Masyarakat Vol. 3, No.1.

Rhina UF, Erlyna WR. (2016). Peningkatan Usaha Susu Kedelai Skala Home Industry. Jurnal Semar, 4(2):11-24.

Setiavani G. (2012). Inovasi Pembuatan Susu Kedelai Tanpa Rasa Langu. Disampaikan pada kegiatan Pelatihan Kewirausahaan Bagi Kelompok Afinitas Kelurahan Mandiri Kerjasama STPP Medan dan Badan Ketahanan Pangan Kota MedanTanggal 1618 April 2012.

Widowati S. (2007). Teknologi Pengolahan Kedelai Dalam Buku Kedelai. Teknik Produksi dan Pengembangan page: 491-521. Bogor (ID): Balai Besar Penelitian dan Pengembangan Pascapanen Pertanian. 